\title{
Cell-surface Proteins of Streptococcus sanguis Associated with Cell Hydrophobicity and Coaggregation Properties
}

\author{
By H. F. JENKINSON \\ Department of Oral Biology and Oral Pathology, University of Otago, PO Box 647, Dunedin, \\ New Zealand
}

(Received 16 October 1985; revised 6 February 1986)

\begin{abstract}
Incubating cells of Streptococcus sanguis with sodium lauroyl sarcosinate, under conditions that did not cause lysis, solubilized material comprising $5-8 \%$ of the cell dry weight. The treatment reduced cell hydrophobicity, and reduced the ability of the cells to coaggregate with Actinomyces spp. The extract contained about 20 polypeptides and these were identified as being cell-surface components on the basis of one or more of the following criteria: $(a)$ being degraded when cells were incubated with protease; $(b)$ being labelled when cells were iodinated using a lactoperoxidase-catalysed reaction; $(c)$ reacting with antibodies raised to fixed whole cells. Eight of the polypeptides accounted for more than $70 \%$ of the total protein extracted, and one component (molecular mass $16 \mathrm{kDa}$ ) was hydrophobic. The cell-surface proteins described are implicated in cell hydrophobicity and coaggregation.
\end{abstract}

\section{INTRODUCTION}

Streptococcus sanguis is one of the first colonizers of the tooth surface and is a major component of human dental plaque (Gibbons \& van Houte, 1975; van Houte et al., 1970; Hamada \& Slade, 1980). Adherence of the organism to the tooth surface involves electrostatic and hydrophobic interactions between surface components of the Streptococcus and adsorbed salivary glycoproteins comprising the pellicle (Murray et al., 1982; Nesbitt et al., 1982a, b; Rosenberg et al., 1983; Eifert et al., 1984). S. sanguis also coaggregates with other oral bacteria (Gibbons \& Nygaard, 1970) and the specific aggregations, such as those with Actinomyces viscosus and $A$. naeslundii (Cisar et al., 1979; Kolenbrander \& Williams, 1981; Sato et al., 1984) contribute to the formation of dental plaque.

It appears that proteins present in the cell envelopes of streptococci mediate attachment of the cells to various surfaces including epithelia (Ellen \& Gibbons, 1972) and salivary pellicle (Liljemark \& Bloomquist, 1981), and to other bacteria (Weerkamp \& McBride, 1981). Following the observation by Weerkamp \& Jacobs (1982) that adherence-defective mutants of $S$. salivarius lacked several of the normal cell-wall proteins, considerable interest has centred on the high molecular mass proteins present in the cell wall of $S$. mutans (Russell, 1979; Nesbitt et al., 1980; Ogier et al., 1984; Smith et al., 1984) and their possible role in adherence. Recently, McBride et al. (1985) have suggested that various proteins present in the cell wall of hydrophobic strains of $S$. sanguis may be involved in adherence of cells to saliva-coated hydroxyapatite.

To identify components at the cell surface of $S$. sanguis involved in adhesion, we have looked first at ways of removing proteins specifically from the surface of the cells. This paper describes the isolation of a number of previously unidentified proteins that are present at the cell surface of $S$. sanguis and that may confer hydrophobicity and coaggregation properties.

\footnotetext{
Abbreviations: BSA, bovine serum albumin; 2-MeH, 2-mercaptoethanol; PAS, periodic acid-Schiff; PMSF, phenylmethylsulphonyl fluoride; SLS, sodium lauroyl sarcosinate.
} 


\section{METHODS}

Chemicals. $N$-Lauroylsarcosine, Nonidet P-40, egg-white lysozyme (EC 3.2.1.17), mutanolysin, chymotrypsin, Streptomyces griseus protease type XIV (pronase), Staphylococcus aureus protease type XVII (V8 protease), lactoperoxidase (EC 1.11.1.7), amino acids, vitamins, and molecular mass markers for gel electrophoresis were purchased from Sigma. Zwittergents were obtained from Calbiochem-Behring. All other chemicals were from BDH unless otherwise stated.

Bacteria. S. sanguis strain OB11 is a Challis strain (serotype 2; Rosan, 1973) kindly provided by Dr F. L. Macrina, Virginia Commonwealth University, Va, USA, and was used throughout this work. Other strains used were FW 35 (serotype 1; Nugent \& Cole, 1977) and Channon (NCTC 7869) (serotype 2; Cole et al., 1976), which were kindly supplied by Dr J. Ranhand, National Institutes of Health, Frederick, Md, USA. Stocks were kept as freeze-dried suspensions in horse serum (Difco); the strains conformed to the physiological description of $S$. sanguis (Hardie \& Bowden, 1976). Actinomyces viscosus strain T14V and A.naes/undii strain W1544 were gifts from Dr J. O. Cisar, National Institute of Dental Research, Bethesda, Md, USA.

Media. Bacteria were cultured on BHYN agar, which contained per litre brain heart infusion broth (Difco), $37 \mathrm{~g}$; yeast extract (Difco), $5 \mathrm{~g}$; neopeptone (Difco), $5 \mathrm{~g}$; and agar, $15 \mathrm{~g}$. Plates were incubated at $37^{\circ} \mathrm{C}$ in a GasPak (BBL) System for 24-36 h. Liquid cultures were grown at $37^{\circ} \mathrm{C}$ in screw-capped bottles or tubes as stationary cultures in BHY medium (brain heart infusion broth, $37 \mathrm{~g} \mathrm{l}^{-1}$; yeast extract, $5 \mathrm{~g} \mathrm{l}^{-1}$ ). S. sanguis was also grown in a defined medium containing glucose, sucrose or lactose as carbon and energy source. The defined medium was based on that described by Carlsson (1972) and contained per litre $\mathrm{K}_{2} \mathrm{HPO}_{4}, 10 \mathrm{~g} ; \mathrm{K} \mathrm{H}_{2} \mathrm{PO}_{4}, 2 \mathrm{~g} ;\left(\mathrm{NH}_{4}\right)_{2} \mathrm{SO}_{4}$, $1.3 \mathrm{~g} ; \mathrm{NaCl}, 2 \mathrm{~g} ; \mathrm{MgSO}_{4} .7 \mathrm{H}_{2} \mathrm{O}, 0.5 \mathrm{~g} ; \mathrm{CaCl}_{2} .2 \mathrm{H}, \mathrm{O}, 0.15 \mathrm{~g} ;$ L-glutamate, $0.5 \mathrm{~g} ;$ L-arginine. $\mathrm{HCl}, 0.2 \mathrm{~g} ; \mathrm{L}-$ cysteine. $\mathrm{HCl}, 0 \cdot 2 \mathrm{~g}$; L-tryptophan, $0 \cdot 02 \mathrm{~g}$; Casamino acids (Difco), $2 \mathrm{~g} ; \mathrm{MnCl}_{2} .4 \mathrm{H}_{2} \mathrm{O}, 20 \mathrm{mg} ; \mathrm{FeCl}_{3} .6 \mathrm{H}_{2} \mathrm{O}, 1 \mathrm{mg}$; pyridoxine $\mathrm{HCl}, 24 \mathrm{mg}$; nicotinic acid, $4.6 \mathrm{mg}$; pantothenic acid, $2.4 \mathrm{mg}$; riboflavin, $0.4 \mathrm{mg}$; thiamin. $\mathrm{HCl}, 0 \cdot 1$ $\mathrm{mg}$; D-biotin, $12 \mu \mathrm{g}$; glucose (sucrose or lactose), $8 \cdot 0 \mathrm{~g}$; initial pH 7.4. Sterile stock solutions of vitamins, $\mathrm{MgSO}_{4}$, $\mathrm{CaCl}_{2}$, glutamate, tryptophan, arginine and cysteine were added to the bulk medium after autoclaving.

Extraction of whole cells. An exponential-phase culture $(10 \mathrm{ml})$ of $S$. sanguis strain OB11 at $\mathrm{OD}_{600} 0.7(1.5 \times$ $10^{9} \mathrm{c}$.f.u. $\mathrm{ml}^{-1}$ ) was centrifuged for $10 \mathrm{~min}$ at $6000 \mathrm{~g}$ at $20^{\circ} \mathrm{C}$, the supernatant was discarded and the cells were washed with $10 \mathrm{ml} 0.15 \mathrm{M}-\mathrm{NaCl}$. To the washed-cell pellet was added $0.2 \mathrm{ml}$ of a $1 \%(\mathrm{w} / \mathrm{v})$ solution of sodium lauroyl sarcosinate (SLS) (or other detergent, see Results) in $10 \mathrm{~mm}-\mathrm{Tris} / \mathrm{HCl}\left(\mathrm{pH} 7.5\right.$ ) containing $1 \mathrm{mM}-\mathrm{Na}_{2}$ EDTA (TE buffer). The cells were vortex-mixed and the suspension was transferred to an Eppendorf microfuge tube. For extraction of cells with other agents, e.g. $1 \mathrm{M}-\mathrm{NaCl}$ or $8 \mathrm{M}$-urea, $0 \cdot 1 \mathrm{ml}$ was used in place of the $0 \cdot 2 \mathrm{ml}$ detergent solution. After $20 \mathrm{~min}$ at $20^{\circ} \mathrm{C}$, the cell suspension was centrifuged $\left(6000 \mathrm{~g}, 10 \mathrm{~min}, 20^{\circ} \mathrm{C}\right)$ and a portion of the supernatant $(0.15 \mathrm{ml})$ was carefully removed from above the pellet into a fresh tube and centrifuged as before. A portion of the supernatant $(0.10 \mathrm{ml})$ was removed, bromophenol blue $(0.01 \%)$ in $70 \%(\mathrm{v} / \mathrm{v})$ glycerol was added $(0.01$ $\mathrm{ml}$ ) and the extract was then either heated at $70^{\circ} \mathrm{C}$ for $10 \mathrm{~min}$ and subjected to electrophoresis (see below) or stored at $-23^{\circ} \mathrm{C}$. To extract a larger quantity of cells, the volume of detergent solution was increased proportionately, and then the extract was diluted with 8 vols $80 \%(\mathrm{v} / \mathrm{v})$ ethanol, left overnight at $-23^{\circ} \mathrm{C}$, and the precipitate was collected by centrifugation $\left(15000 \mathrm{~g}, 20 \mathrm{~min}, 4^{\circ} \mathrm{C}\right)$. The pellet was suspended in distilled water $(0.5-1.0 \mathrm{ml})$, and stored at $-23^{\circ} \mathrm{C}$.

Protease treatment of cells. Exponential-phase cells were harvested and washed as described above, and the pellet was suspended in $10 \mathrm{~mm}$-Tris $/ \mathrm{HCl}, \mathrm{pH} 7.5\left(1 \mathrm{ml}\right.$ ). Pronase (stock solution $10 \mathrm{mg} \mathrm{ml}^{-1}$ in $10 \mathrm{~mm}-\mathrm{Tris} / \mathrm{HCl}$, $0 \cdot 15 \mathrm{M}-\mathrm{NaCl}, \mathrm{pH} 7 \cdot 5$, self-digested for $2 \mathrm{~h}$ at $37^{\circ} \mathrm{C}$ ), chymotrypsin or $\mathrm{V} 8$ protease (stock solutions $10 \mathrm{mg} \mathrm{ml}^{-1}$ also in Tris/ $\mathrm{NaCl}$ ) was added, and the suspension was incubated at $20^{\circ} \mathrm{C}$ for $20 \mathrm{~min}$. Distilled water was added to $10 \mathrm{ml}$, the suspension was centrifuged $(6000 \mathrm{~g}, 5 \mathrm{~min})$, and the pellet was suspended in $10 \mathrm{~mm}-\mathrm{Tris} / \mathrm{HCl}, \mathrm{pH} 7 \cdot 5$ containing $1 \mathrm{~mm}$-phenylmethylsulphonyl fluoride (PMSF). The cells were pelleted by centrifugation as before, washed again and then extracted with SLS as described above.

Electron microscopy. Cells were fixed with $1 \%(\mathrm{w} / \mathrm{v})$ osmium tetroxide, embedded in Epon 812 resin, then thinsectioned, stained with uranyl acetate and examined. For negative-staining, one drop of turbid cell suspension was placed on a Formvar grid, excess liquid was removed with filter paper, and the grid was then allowed to dry for 5 min at $20^{\circ} \mathrm{C}$. Phosphotungstic acid $(1 \%, w / v ; 5 \mu l)$ was added for $10 \mathrm{~s}$ and excess was dried off with filter paper.

Cell fractionation. Exponential-phase cells $(100 \mathrm{ml}$ culture) were harvested by centrifugation $(6000 \mathrm{~g}, 10 \mathrm{~min}$, $4{ }^{\circ} \mathrm{C}$ ), the supernatant was discarded and the pellet was washed with $50 \mathrm{ml} 0 \cdot 15 \mathrm{M}-\mathrm{NaCl}$. The pellet was suspended in $10 \mathrm{~mm}$-Tris $/ \mathrm{HCl}, \mathrm{pH} 7 \cdot 5$, containing $1 \mathrm{~mm}$-EDTA and $1 \mathrm{~mm}$-PMSF (TEP buffer) and the cells were broken by shaking them with glass beads $(0 \cdot 10-0 \cdot 11 \mathrm{~mm}$ diam.; $7 \mathrm{ml}$ beads plus $10 \mathrm{ml}$ cells $)$ in a Braun homogenizer run at full speed for $4 \mathrm{~min}$ with carbon dioxide cooling to $4{ }^{\circ} \mathrm{C}$. The beads were allowed to settle and the suspension was decanted. The beads were washed with TEP buffer $(5 \mathrm{ml})$, the washing was combined with the broken cell suspension, and the suspension centrifuged $\left(3000 \mathrm{~g}, 5 \mathrm{~min}, 4^{\circ} \mathrm{C}\right)$. The supernatant was decanted off the pellet into a fresh tube and re-centrifuged as before, and the process was repeated a further time. Finally, the supernatant was removed carefully from the pellet leaving approximately $1 \mathrm{ml}$ behind with the pellet, and the supernatant was centrifuged for $90 \mathrm{~min}$ at $100000 \mathrm{~g}\left(4^{\circ} \mathrm{C}\right)$. The supernatant from this centrifugation is referred to as the "high-speed 
supernatant', and the pellet is referred to as the 'cell-envelope fraction'. To extract proteins for electrophoresis, the cell-envelope fraction was suspended in $10 \mathrm{~mm}$-Tris $/ \mathrm{HCl}, \mathrm{pH} 8 \cdot 8$, containing $1 \%(\mathrm{w} / \mathrm{v})$ SDS and $0 \cdot 5 \%(\mathrm{v} / \mathrm{v}) 2$ mercaptoethanol $(2-\mathrm{MeH})$, heated at $70^{\circ} \mathrm{C}$ for $10 \mathrm{~min}$, and then centrifuged $\left(5000 \mathrm{~g}, 5 \mathrm{~min}, 20^{\circ} \mathrm{C}\right)$. The clarified supernatant was mixed with bromophenol blue and glycerol as described above and subjected to SDS-PAGE.

Solubilization of cell wall. After extraction of the envelope fraction with SDS/2-MeH, the pellet was suspended in distilled water $(0.2 \mathrm{ml})$ and boiled for $10 \mathrm{~min}$. The suspension was centrifuged $\left(5000 \mathrm{~g}, 10 \mathrm{~min}, 20^{\circ} \mathrm{C}\right)$, the pellet was suspended in $0.5 \mathrm{ml}$ distilled water and heated again to $100^{\circ} \mathrm{C}$ for $10 \mathrm{~min}$, and then centrifuged as before. The pellet was suspended in $0.2 \mathrm{ml} 10 \mathrm{~mm}$-Tris/ $\mathrm{HCl}, \mathrm{pH} 7.5$, containing $0.1 \mathrm{M}-\mathrm{NaCl}$, lysozyme $\left(1 \mathrm{mg} \mathrm{ml}^{-1}\right)$ and mutanolysin (20 units), a drop of toluene was added and the mixture was incubated for $14 \mathrm{~h}$ at $37^{\circ} \mathrm{C}$. After adding SDS to a final concentration of $1 \%$ and $2-\mathrm{MeH}$ to $0.5 \%$, the suspension was heated at $70{ }^{\circ} \mathrm{C}$ for 10 min and centrifuged, and the supernatant was mixed with glycerol and bromophenol blue for electrophoresis.

Concentration of exocellular culture fluid. An exponential-phase culture (51) of $S$. sanguis in defined medium containing glucose was centrifuged at $5000 \mathrm{~g}$ for $10 \mathrm{~min}\left(4^{\circ} \mathrm{C}\right)$ and the supernatant (exocellular fluid) was filtered under vacuum through a Whatman GF/C glass fibre filter. The filtrate was concentrated to $200 \mathrm{ml}$ by ultrafiltration through an Ulvac membrane ( $10 \mathrm{kDa}$ cut-off). The concentrate was brought to $70 \%$ saturation with ammonium sulphate at $4{ }^{\circ} \mathrm{C}$ and, after several hours of stirring the suspension, the precipitate was collected by centrifugation at $7000 \mathrm{~g}$ for $20 \mathrm{~min}\left(4^{\circ} \mathrm{C}\right)$. The pellet was suspended in TEP buffer and dialysed against deionized water $(5 \mathrm{l})$ for $16 \mathrm{~h}$ at $4{ }^{\circ} \mathrm{C}$. The dialysed suspension contained about $2 \mathrm{mg}$ protein $\mathrm{ml}^{-1}$, as measured by the Lowry method. For electrophoresis, a portion was mixed with an equal volume of $10 \mathrm{~mm}$-Tris/ $\mathrm{HCl}, \mathrm{pH} 8.8$, containing $2 \%(\mathrm{w} / \mathrm{v})$ SDS and $1 \%(\mathrm{v} / \mathrm{v}) 2-\mathrm{MeH}$, heated to $70{ }^{\circ} \mathrm{C}$ for $10 \mathrm{~min}$, and mixed with tracking dye and glycerol as described above.

$S D S-P A G E$. Samples were electrophoresed through $13 \%(\mathrm{w} / \mathrm{v})$ acrylamide gels containing $0 \cdot 1 \%$ SDS by the system of Laemmli \& Favre (1973). Gels were stained with Coomassie blue, de-stained, scanned with a densitometer, and autoradiographed as described by Jenkinson et al. (1981). Gels were silver-stained by the method of Merril et al. (1981) and stained for carbohydrate by the periodic acid-Schiff (PAS) procedure of Fairbanks et al. (1971). Molecular masses of proteins were estimated from their distances of migration by reference to a plot relating migration distances for six marker proteins to log molecular mass. The markers were bovine serum albumin (BSA) (66 kDa), chicken egg albumin ( $45 \mathrm{kDa})$, glyceraldehyde-3-phosphate dehydrogenase $(36 \mathrm{kDa})$, carbonic anhydrase $(29 \mathrm{kDa})$, soybean trypsin inhibitor $(20 \mathrm{kDa})$ and bovine milk $\alpha$-lactalbumin $(14.2 \mathrm{kDa})$. Proteins were transferred from acrylamide gels to nitrocellulose by electroblotting (Towbin et al., 1979 ) in $25 \mathrm{~mm}$-Tris, $192 \mathrm{~mm}$-glycine, $20 \%(\mathrm{w} / \mathrm{v})$ methanol, $\mathrm{pH} 8 \cdot 3$, at $30 \mathrm{~V}$ for $16 \mathrm{~h}$.

Phenol extraction of cells. Cells in exponential phase were harvested by centrifugation $\left(6000 \mathrm{~g}, 10 \mathrm{~min}, 4^{\circ} \mathrm{C}\right)$, washed with $0.15 \mathrm{M}-\mathrm{NaCl}$ and suspended to $5 \mathrm{mg} \mathrm{ml}^{-1}$ in $0.01 \mathrm{M}-\mathrm{MgSO}_{4}$. A crude lipoteichoic acid preparation was obtained by hot $\left(68^{\circ} \mathrm{C}\right)$ phenol extraction as described by Kessler \& Shockman (1979).

Antiserum and immunodetection. Antibodies to glutaraldehyde-fixed cells were raised in New Zealand male rabbits. Cells $\left(70 \mathrm{mg}\right.$ dry wt) were fixed with $0 \cdot 25 \%(\mathrm{v} / \mathrm{v})$ glutaraldehyde in $0 \cdot 1 \mathrm{M}-\mathrm{K} \mathrm{H}_{2} \mathrm{PO}_{4} / \mathrm{KOH}$, pH 7 , containing $0.15 \mathrm{M}-\mathrm{NaCl}$ (PBS) at room temperature for $40 \mathrm{~min}$. They were then diluted to $10 \mathrm{ml}$ with PBS, washed three times with PBS, suspended in PBS and portions $\left(0.5 \mathrm{ml}\right.$ containing approx. $8 \times 10^{10}$ cells $)$ were injected intramuscularly on four separate occasions at intervals of $3 \mathrm{~d}$. Then $20 \mathrm{~d}$ after the last of these injections, the rabbits were boosted with a further $5 \times 10^{10}$ cells in PBS $(0.5 \mathrm{ml})$, and bled after 5-7 d. Antibodies to extracellular material were raised as follows: a portion $(0.25 \mathrm{ml})$ of suspension containing approximately $2 \mathrm{mg}$ protein $\mathrm{ml}^{-1}$ in PBS was mixed with an equal volume of Freund's complete adjuvant (Gibco Laboratories) and injected intramuscularly. After $21 \mathrm{~d}$, the rabbits were boosted with an identical injection to the first, and bled after a further 5-7 d. Six weeks later, they were given another booster and bled again 5-7 d later. Proteins blotted on to nitrocellulose were detected by antibody-binding as follows: the blot was blocked with $3 \%(\mathrm{w} / \mathrm{v}) \mathrm{BSA}$ in PBS $(\mathrm{pH} 7.5)$ for $1 \mathrm{~h}$ at $20^{\circ} \mathrm{C}$, and then incubated with antiserum diluted 200 -fold in $1 \%(\mathrm{w} / \mathrm{v})$ BSA in PBS $(\mathrm{pH} 7 \cdot 5)$ for $2-3 \mathrm{~h}$ at $20^{\circ} \mathrm{C}$. The blot was washed twice with $0.1 \%$ Tween 20 in PBS $(50 \mathrm{ml}, 10$ min each time), and then incubated in $100 \mathrm{ml} 1 \%(\mathrm{w} / \mathrm{v})$ BSA in PBS containing $0.2 \mu \mathrm{g}\left[{ }^{125} \mathrm{I}\right]$ Protein A labelled by the chloramine-T method (Greenwood et al., 1963) to a specific activity of $10-20 \mu \mathrm{Ci} \mu \mathrm{g}^{-1}\left(370-740 \mathrm{~Bq} \mu \mathrm{g}^{-1}\right)$. After $1-2 \mathrm{~h}$ incubation at $20^{\circ} \mathrm{C}$ the blots were washed with $0.1 \%$ Tween 20 in PBS (five times, $50 \mathrm{ml}$ each) and then with PBS until the spent wash fluid was virtually free of radioactivity. The blots were dried at $60{ }^{\circ} \mathrm{C}$ for $10 \mathrm{~min}$, then exposed to Kodak medical X-ray film at room temperature for $1-5 \mathrm{~d}$ as necessary. To check that the proteins had blotted on to the nitrocellulose paper, the blot was stained with India ink (Hancock \& Tsang, 1983) either before or after autoradiography. A lane of molecular mass marker proteins was included in each blot and by staining the blot with ink after autoradiography an accurate estimation of the molecular masses of the reactive antigens was obtained.

Surface iodination of cells. Cells (approximately $70 \mathrm{mg} \mathrm{dry} \mathrm{wt}$ ) were harvested from exponential-phase cultures by centrifugation $\left(6000 \mathrm{~g}, 10 \mathrm{~min}, 4{ }^{\circ} \mathrm{C}\right)$, washed once with $0.15 \mathrm{M}-\mathrm{NaCl}$ and suspended to a density of $30 \mathrm{mg}$ dry wt $\mathrm{ml}^{-1}$ in PBS. A portion of the cell suspension $(1 \mathrm{ml})$ was mixed with ${ }^{125} \mathrm{I}(0.5 \mathrm{mCi} ;$ Amersham), and the cells were surface-labelled using lactoperoxidase and hydrogen peroxide by the method of Marchalonis (1969) and the procedure described by Swanson et al. (1975). The reaction was terminated by adding $5 \mathrm{~mm}$-L-cysteine. $\mathrm{HCl}$ in $\mathrm{PBS}$ 
containing $5 \mathrm{mM}-\mathrm{KI}$. The cells were harvested by centrifugation $\left(5000 \mathrm{~g}, 10 \mathrm{~min}, 4^{\circ} \mathrm{C}\right)$ and then washed twice with $10 \mathrm{mM}$-Tris $/ \mathrm{HCl}$, pH $7 \cdot 5$, containing $1 \mathrm{mM}$-PMSF. The specific activity of the radio-iodinated cells was $0 \cdot 2-0 \cdot 5$ $\mu \mathrm{Ci}$ (mg cell dry wt) ${ }^{-1}$. To measure radioactivity in various fractions from broken cells, portions $(0.01-0.02 \mathrm{ml})$ were added to $5 \mathrm{ml} 5 \%(\mathrm{w} / \mathrm{v}) \mathrm{TCA}$ at $4{ }^{\circ} \mathrm{C}$. BSA solution was added $\left(1 \mathrm{ml}, 50 \mu \mathrm{g} \mathrm{ml}^{-1}\right)$, mixed, and after $10 \mathrm{~min}$ the precipitate was collected by filtration under vacuum through a Whatman $\mathrm{GF} / \mathrm{C}$ fibre filter. The filters were washed under vacuum with $5 \%(\mathrm{w} / \mathrm{v})$ TCA $(10 \mathrm{ml})$ and with absolute ethanol $(10 \mathrm{ml})$, and then counted for radioactivity in an LKB 1271 Riagamma counter.

Hydrophobic interaction chromatography. A sample of SLS extract $(0.2 \mathrm{ml})$ containing about $20 \mu \mathrm{g}$ protein was made to $1 \mathrm{M}$ in ammonium sulphate and applied to a column of Octyl-Sepharose CL-4B (Pharmacia), bed volume 2

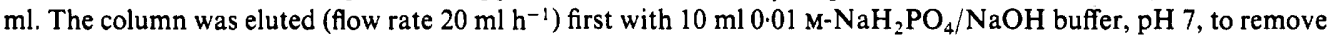
unbound material, and then with a gradient of decreasing ammonium sulphate concentration and increasing SLS concentration (final concentrations $0 \mathrm{~g} \mathrm{l}^{-1}$ and $5 \mathrm{~g} \mathrm{l}^{-1}$ respectively). Fractions $(0.2 \mathrm{ml})$ were collected, mixed with $1.3 \mathrm{ml} \mathrm{4} \%(\mathrm{w} / \mathrm{v}) \mathrm{TCA}$ and, after they had stood at $4{ }^{\circ} \mathrm{C}$ for $1 \mathrm{~h}$, the precipitated protein was pelleted by centrifugation, dissolved in sample buffer and subjected to SDS-PAGE.

Cell hydrophobicity. Exponential-phase cells were washed twice with PUM buffer (containing per litre $22.2 \mathrm{~g}$ $\mathrm{K}_{2} \mathrm{HPO}_{4} .3 \mathrm{H}_{2} \mathrm{O}, 7 \cdot 2 \mathrm{~g} \mathrm{KH}_{2} \mathrm{PO}_{4}, 1.8 \mathrm{~g}$ urea, $0.2 \mathrm{~g} \mathrm{MgSO}_{4} .7 \mathrm{H}_{2} \mathrm{O}$, pH $7 \cdot 1$; Rosenberg et al., 1980) and suspended to an $\mathrm{OD}_{600}$ of approx. $0.6\left(1 \times 10^{9}\right.$ c.f.u. $\left.\mathrm{ml}^{-1}\right)$ in PUM buffer $(1.5 \mathrm{ml})$ and vortex-mixed with hexadecane or xylene for $2 \mathrm{~min}$ (Rosenberg et al., 1980). After allowing the suspensions to settle for $15 \mathrm{~min}$ to permit phase separation, the decrease in $\mathrm{OD}_{450}$ of the aqueous lower phase was used as a measure of the cell-surface hydrophobicity.

Coaggregation assay. $A$. viscosus $\mathrm{T} 14 \mathrm{~V}$ and $A$. naeslundii W1544 were grown in BHY medium and harvested in mid-exponential phase of growth $\left(\mathrm{OD}_{600}\right.$ approx. 0.7$)$. The cells were washed by three cycles of centrifugation $\left(6000 \mathrm{~g}, 10 \mathrm{~min}, 4^{\circ} \mathrm{C}\right)$ and suspension of the pellet in coaggregation buffer $(1 \mathrm{~mm}-\mathrm{Tris} / \mathrm{HCl}, \mathrm{pH} 8 \cdot 0$, containing $0 \cdot 1$ $\mathrm{mM}-\mathrm{MgCl}_{2}, 0 \cdot 1 \mathrm{mM}-\mathrm{CaCl}_{2}$ and $0.15 \mathrm{M}-\mathrm{NaCl}$; Cisar et al., 1979). Cells of $S$. sanguis were grown in defined medium with glucose and prepared for coaggregation in an identical fashion. Actinomycete cell suspension $\left(1 \mathrm{ml} ; \mathrm{OD}_{600}\right.$ approx. 0.5 , equivalent to $5 \times 10^{8}$ c.f.u. $\mathrm{ml}^{-1}$ ) was vortex-mixed for $10 \mathrm{~s}$ with an equal volume of $S$. sanguis cell suspension containing about $1 \times 10^{9} \mathrm{c}$.f.u. $\mathrm{ml}^{-1}\left(\mathrm{OD}_{600}\right.$ approx. 0.6$)$. Controls of actinomycete or streptococcal cell suspensions alone were included in every assay. The suspensions were allowed to stand at room temperature for $3 \mathrm{~h}$, then scored for coaggregation. They were then allowed to stand at room temperature overnight, mixed the next day, and scored again after $2 \mathrm{~h}$. The degree of coaggregation was scored as 0 (negative), 1 (questionable), 2 (weak) or 4 (marked). The extent of coaggregation between bacterial pairs was also determined spectrophotometrically and expressed as a percentage, as described by Cisar et al. (1979), but using the coaggregation buffer described above.

Thin-layer chromatography (TLC). Cell extracts were made to $1 \mathrm{M}-\mathrm{HCl}$ and heated to $100^{\circ} \mathrm{C}$ in sealed vials for 60 min (partial hydrolysis) or for $10 \mathrm{~h}$ (complete hydrolysis). The hydrolysates were freeze-dried, suspended in distilled water and portions were applied to the origin of a strip of TLC aluminium roll pre-coated with silica gel 60 $\mathrm{F}_{254}$ (Merck). The sugars were separated by ascending chromatography, using a solvent containing propan-1ol/acetone/1 M-lactic acid ( $7: 1: 1$, by vol.). The chromatogram was sprayed with aniline/diphenylamine (Hansen, 1975 ), and the blue sugar spots were developed by heating the chromatogram at $110^{\circ} \mathrm{C}$ for $30-60 \mathrm{~min}$. Sugars were identified by comparison of their $R_{F}$ values with those of standard sugars run on the same chromatogram.

Amino acids and phosphate esters were separated by TLC in a solvent containing propan-1-ol/ammonia/water $(6: 3: 1$, by vol.) (Archibald, 1972). The chromatogram was sprayed first with ninhydrin $(0.2 \%, w / v)$ in acetone and heated briefly at $100^{\circ} \mathrm{C}$ to detect amino compounds. It was then sprayed with ammonium molybdate (Mann et al., 1979 ) to detect phosphate. Suitable standards were run with each set of samples.

Estimation of hexose, phosphorus and protein. Hexose was determined by the phenol/sulphuric acid method of Dubois et al. (1956), using D-glucose as standard, and phosphorus was estimated as inorganic phosphate by the method of Chen et al. (1956), using $\mathrm{K}_{2} \mathrm{HPO}_{4}$ as standard. Protein concentration was measured by the Lowry method with BSA as standard.

\section{RESULTS}

\section{Extraction of cell-surface proteins}

Experiments were initially done to find a suitable method for removing cell-surface proteins of $S$. sanguis strain OB 11 without disrupting the cells. Cells were treated with a variety of agents, e.g. high salt, EDTA, chaotropic salts and detergents, the extracts obtained were subjected to SDS-PAGE and the fractionated proteins were identified by staining the gels with silver nitrate.

No significant amount of protein (as detected by silver-staining of extracts subjected to SDSPAGE) was removed from the cells when they were treated with $1 \mathrm{M}-\mathrm{NaCl}, 1 \mathrm{M}-\mathrm{MgCl}_{2}$ or $0 \cdot 1 \mathrm{M}$ EDTA at $20^{\circ} \mathrm{C}$ for $20 \mathrm{~min}$. On the other hand, extracts from cells incubated at $20^{\circ} \mathrm{C}$ for $20 \mathrm{~min}$ with $1 \%(\mathrm{w} / \mathrm{v})$ SDS contained 15 to 20 polypeptides (Fig. 1, lane A). A similar gel pattern was 


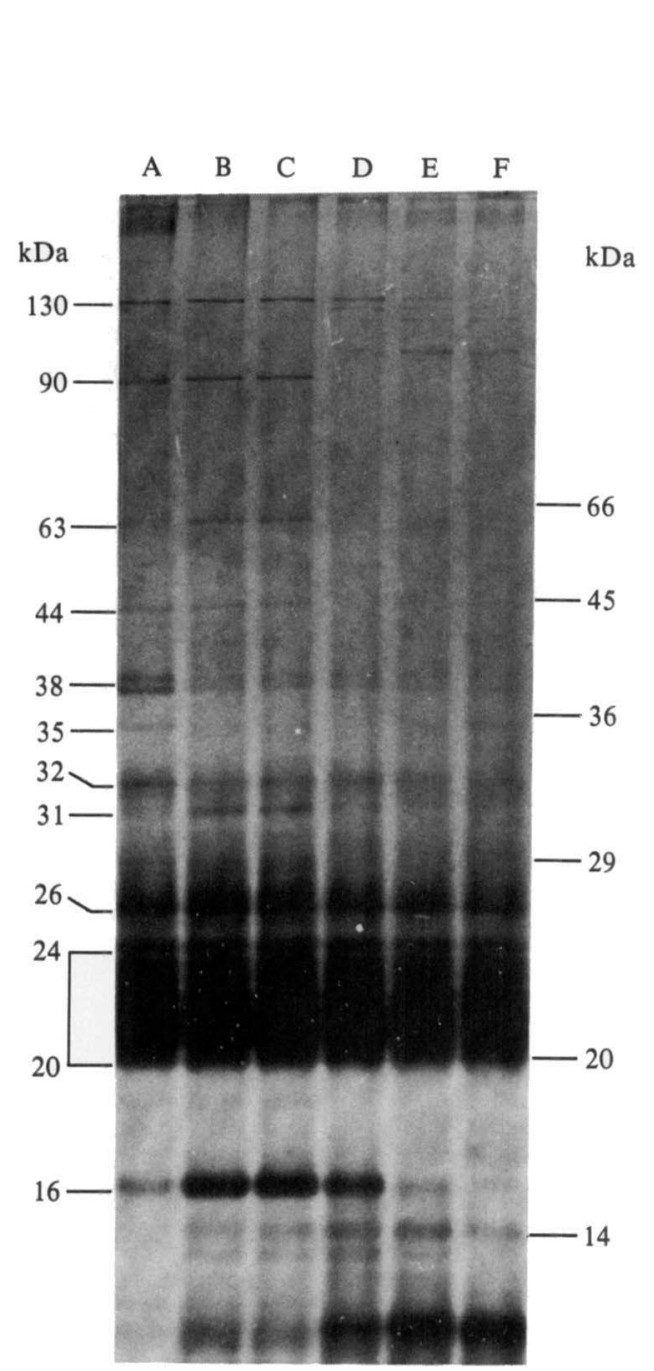

Fig. 1

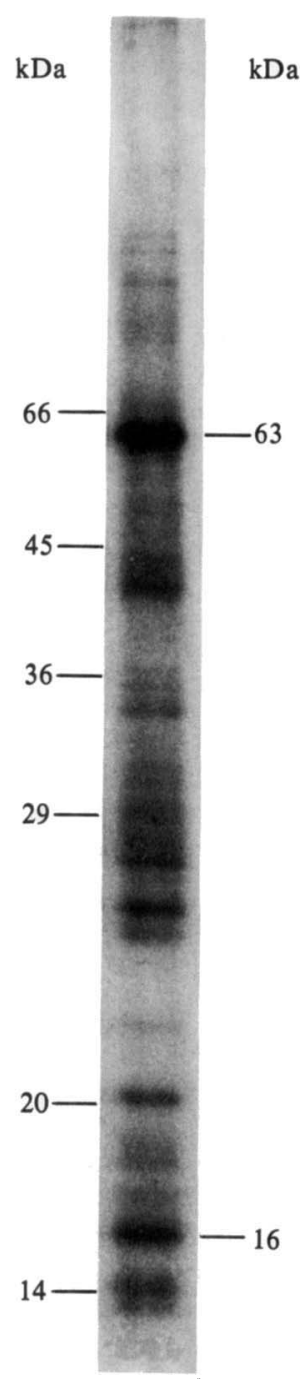

Fig. 2

Fig. 1. SDS-PAGE pattern of proteins (stained with silver nitrate) extracted from cells of $S$. sanguis strain OB11 with SDS (lane A), SLS (lane B), and with SLS from cells incubated for 20 min at $20^{\circ} \mathrm{C}$ with various concentrations of pronase $\left(\mu \mathrm{g} \mathrm{ml}^{-1}\right)$ : zero (lane C), 20 (lane D), 50 (lane E) and 100 (lane F). The positions of molecular mass markers are indicated for reference on the right and the protein bands in the detergent extracts are labelled according to their apparent molecular masses on the left. Samples each contained about $5 \mu \mathrm{g}$ protein (Lowry).

Fig. 2. Autoradiogram of ${ }^{125} \mathrm{I}$-labelled proteins extracted from $S$. sanguis cells with SLS and separated by SDS-PAGE. Positions of molecular mass marker proteins are shown on the left and the prominent iodinated protein bands are labelled according to their approximate molecular masses on the right.

obtained for extracts with $8 \mathrm{M}$-urea, although the amount of protein extracted was estimated to be at least 10-fold less (results not shown). Since detergent extraction seemed the most promising method for removing protein, cells were incubated with solutions of various detergents to see if these would extract different proteins. However, the SDS-PAGE profiles of proteins extracted with $1 \%$ solutions of the following detergents were identical: SLS, Nonidet P-40, Zwittergent $3: 12$, Zwittergent $3: 16$. The protein profile of the SLS extract was representative of the different detergent extracts (Fig. 1, lane B); interestingly, these detergents all removed a $16 \mathrm{kDa}$ 
protein from the cells which SDS effectively did not (see Fig. 1, lane A). Extraction with SLS removed about $2.7 \%$ of total cell protein as estimated by the Lowry method. The proteins extracted with SLS ranged in molecular mass from about $130 \mathrm{kDa}$ to $12 \mathrm{kDa}$ (Fig. 1, lane B). Some of the more prominent components are labelled in Fig. 1 according to their approximate molecular masses $(\mathrm{kDa})$; the designations are intended as a guide to protein identification rather than accurate molecular mass determinations. Densitometry of the silver-stained gel (Fig. 1, lane B) showed that seven polypeptides in the range $20-24 \mathrm{kDa}$ accounted for $50-60 \%$ of the total stained extract and, also, that the $16 \mathrm{kDa}$ polypeptide comprised about $15 \%$ of the total. The other polypeptide bands identified were relatively minor components, but were always present. Increasing the temperature of extraction to $40^{\circ} \mathrm{C}$ resulted in a smeared SDS-PAGE profile indicative of a complex mixture of proteins. The pattern in Fig. 1 (lane B) was not altered either by washing the cells up to four times (with water, $0.15 \mathrm{M}-\mathrm{NaCl}$ or $10 \mathrm{mM}-\mathrm{Tris} / \mathrm{HCl}, \mathrm{pH} 7 \cdot 5$ ) before extraction, or by including $1 \mathrm{~mm}-\mathrm{PMSF}$ (serine protease inhibitor) in the washing and extraction solutions. Neither the phase of growth (exponential or stationary) nor the carbon source (glucose, lactose or sucrose) in a semi-defined medium affected the SDS-PAGE pattern as shown in Fig. 1 (lane B). Also, cells of strain Channon and strain FW35 (see Methods) were extracted with SLS and the protein profiles after SDS-PAGE were identical to that for the Challis serotype 2 strain OB11 (results not shown).

\section{Protease treatment of cells}

To determine if the polypeptides extracted with SLS were surface proteins, cells were incubated with different concentrations of various proteases and then treated with SLS. Proteins normally present in the SLS extract and either diminished or absent in SLS extracts of proteasetreated cells were likely to be accessible at the cell surface. Pre-treatment of cells with chymotrypsin $\left(100 \mu \mathrm{g} \mathrm{ml}^{-1}\right)$ as described in Methods had no effect on the SDS-PAGE pattern of proteins extracted with SLS (results not shown). In contrast, a number of the proteins normally present in the SíS extract were absent in extracts of cells that had been treated with either $S$. aureus V8 protease or with S. griseus protease (pronase E). Fig. 1 (lanes C, D, E and F) shows the effect of incubating the cells with pronase on the SDS-PAGE pattern of proteins extracted with SLS. With the exception of those polypeptides in the $20-26 \mathrm{kDa}$ range, all the proteins normally present in the SLS extract were either absent, or their amounts were reduced, in the SLS extract of pronase-treated cells. To show that the protease was only acting before SLS treatment (and not during the subsequent extraction), pronase $\left(100 \mu \mathrm{g} \mathrm{ml}^{-1}\right)$ was added to cells which were then immediately washed, as described in Methods, and incubated with SLS. The SDS-PAGE pattern of proteins in this extract (Fig. 1, lane C) was identical to that of the untreated cells (Fig. 1 , lane B). All of the proteins in the SLS extract were susceptible to pronase because they were degraded when a portion of an extract $(40 \mu \mathrm{l})$ was incubated with the enzyme $(1 \mu \mathrm{g}, 10 \mathrm{~min}$, $20^{\circ} \mathrm{C}$ ), and then subjected to SDS-PAGE (results not shown). These results suggest that with the exception of the proteins in the 20-24 kDa group (which either are not surface proteins or, in situ, are not susceptible to pronase), the protein components of the SLS extract are at the cell surface.

\section{Lactoperoxidase-catalysed iodination of cell-surface proteins}

Confirmation that SLS extracted surface proteins was sought by surface-labelling cells of $S$. sanguis with ${ }^{125} \mathrm{I}$, using a lactoperoxidase-catalysed reaction. The iodinated cells were extracted with SLS and the labelled proteins, i.e. those exposed on the surface, were separated by SDSPAGE and identified by autoradiography.

Treatment of iodinated cells with SLS removed $37 \%$ of the TCA-precipitable radioactivity. The extract contained about 30 iodinated polypeptides (Fig. 2), a number of which were not previously visualized by silver-staining (see Fig. 1). The major labelled components were the 63 $\mathrm{kDa}$ and $16 \mathrm{kDa}$ polypeptides (Fig. 2). The $26 \mathrm{kDa}, 24 \mathrm{kDa}$ and $20 \mathrm{kDa}$ proteins that were not degraded by pronase treatment of cells were nonetheless iodinated (Fig. 2), indicating that they are surface-exposed. The remaining five polypeptides in the $20-24 \mathrm{kDa}$ group were not surfacelabelled. 
Table 1. Composition of SLS extract from cells of S. sanguis

The values are means of triplicate samples, none of which varied by more than $7 \%$ from the mean. ND, Not determined.

\begin{tabular}{|c|c|c|c|}
\hline & $\begin{array}{c}\text { Before acid } \\
\text { hydrolysis } \\
(\mu \mathrm{g})\end{array}$ & $\begin{array}{l}\text { After acid } \\
\text { hydrolysis } \\
\qquad(\mu \mathrm{g})\end{array}$ & $\begin{array}{l}\text { Percentage of } \\
\text { extract dry wt }\end{array}$ \\
\hline Dry weight & 360 & ND & - \\
\hline Hexose* & 32 & 37 & $10 \cdot 2$ \\
\hline Protein (Lowry) & 25 & ND & 6.9 \\
\hline Phosphorus & $<3$ & 40 & $11 \cdot 1$ \\
\hline
\end{tabular}

\section{Effect of protease or SLS treatments on cell morphology}

Cells that had been incubated with SLS and then plated out on to BHY agar did not form colonies. Pronase treatment, on the other hand, did not affect viability. Neither treatment caused gross changes in cell morphology as ascertained by phase-contrast microscopy. However, there was an indication in electron micrographs of thin sections of SLS-treated cells that the cell surface was disturbed, so cells were negatively-stained to reveal fibrillar surface structures (Handley et al., 1985). Pronase treatment of the cells did not significantly alter the fibrillar surface, but SLS treatment appeared to reduce the numbers of fibrils (results not shown).

\section{Analysis of SLS-extracted material}

Approx. 500 mg equiv. dry wt cells of $S$. sanguis were incubated with SLS, and the extracted material was precipitated with ethanol and collected as described in Methods. Portions of it were dried to constant weight at $85^{\circ} \mathrm{C}$, and other samples were assayed before and after acid hydrolysis for protein, phosphorus and carbohydrate. The SLS-extracted material comprised 5$8 \%$ of the cell dry weight, and contained (by weight) $10.2 \%$ hexose, $11.1 \%$ phosphorus and $7 \%$ protein (Lowry method) (Table 1). Phosphorus was only detected after acid hydrolysis of the extract (the assay measures inorganic phosphate).

To determine if the SLS extract contained nucleic acids, portions were subjected to gel electrophoresis through $1 \%(\mathrm{w} / \mathrm{v})$ agarose, and the gel was incubated with ethidium bromide solution $\left(0.5 \mu \mathrm{g} \mathrm{ml}^{-1}\right)$ to stain nucleic acids. The extract contained some high molecular mass DNA, which was susceptible to degradation by DNAase I, but no RNA. It was estimated that $<5 \%$ of the total extract was DNA and, therefore, this would not contribute significantly to the phosphorus estimation.

Partial and complete acid hydrolysates of SLS-extracted material were analysed for component sugars by TLC. Glucose, galactose and rhamnose were present and the pattern of sugars was identical to that obtained when an acid hydrolysate of a crude lipoteichoic acid preparation (extracted from cells with phenol; Wicken et al., 1973) was subjected to TLC.

Hydrolysates of the SLS and phenol extracts were also subjected to TLC in a different solvent to that used for the sugars, and the plates were sprayed first to detect ninhydrin-positive compounds, and then to detect phosphorus. The hydrolysate of the SLS extract, but not that of the phenol extract, contained ninhydrin-positive spots. Similar patterns of phosphate esters were present in both extracts. Thus, the SLS extract contained, in addition to protein, material similar in composition to that extracted from cells with aqueous phenol, (that is, mainly lipoteichoic acid).

\section{$S D S-P A G E$ patterns of proteins from extracellular and subcellular fractions}

Cells of $S$. sanguis secreted 30 or so polypeptides into the culture fluid during growth (Fig. 3, lane B), the major proteins having molecular masses of $44 \mathrm{kDa}$ and $66 \mathrm{kDa}$. While the SLS extract from cells contained several of the culture fluid proteins, e.g. $44 \mathrm{kDa}, 31 \mathrm{kDa}, 28 \mathrm{kDa}$, the SDS-PAGE patterns of proteins in the two extracts were, in general, quite different (Fig. 3, 


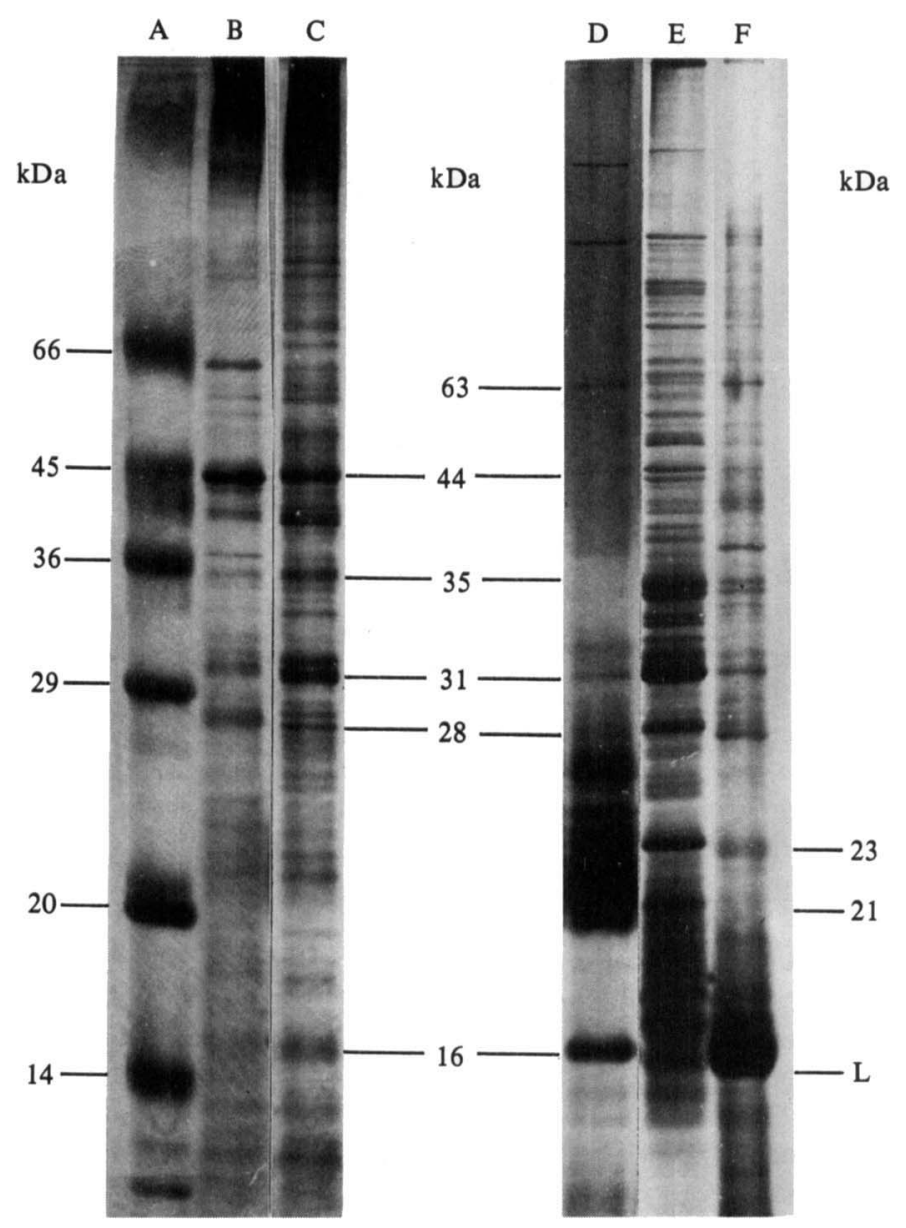

Fig. 3. SDS-PAGE patterns of proteins (stained with silver nitrate) from various subcellular fractions. Lanes: A, molecular mass markers; B, culture supernatant; C, high-speed supernatant (soluble) fraction; D, SLS extract; E, cell-envelope fraction; F, cell-wall fraction. The derivations of the various fractions are described in Methods. Protein bands are labelled according to their approximate molecular masses. L, lysozyme. Each lane contained 5-10 $\mu \mathrm{g}$ protein.

lanes B and D). The $16 \mathrm{kDa}$ cell-surface protein extracted with SLS was present in a high-speed supernatant fraction prepared from broken cells (Fig. 3, lane C). This polypeptide appears to be solubilized from the cell surface upon breakage of the cells.

The cell-envelope fraction was dominated by bands at $35 \mathrm{kDa}, 31 \mathrm{kDa}$ and $28 \mathrm{kDa}$, and a group of proteins between 16 and $20 \mathrm{kDa}$ (Fig. 3, lane E). After extracting the envelopes with SDS/2-MeH, the residue was digested with a mixture of lysozyme and mutanolysin, and then reextracted. The SDS-PAGE profile of this wall extract contained no major new bands (Fig. 3, lane F). The polypeptide band at about $37 \mathrm{kDa}$ in the wall extract stained with PAS reagent; no other protein bands in any of the gels stained for carbohydrate with PAS.

Comparison of the gel patterns shows that several of the dominant bands in the cell-envelope and cell-wall extracts, e.g. 31,28 and $23 \mathrm{kDa}$ bands, were minor components in the SLS extract. In general, though, the SDS-PAGE pattern of proteins in the SLS extract bore little similarity to the pattern of proteins in the envelope or wall extracts. Thus, incubation of cells with SLS provides an extract containing, as major components, proteins that are not easily identified in other subcellular fractions. 


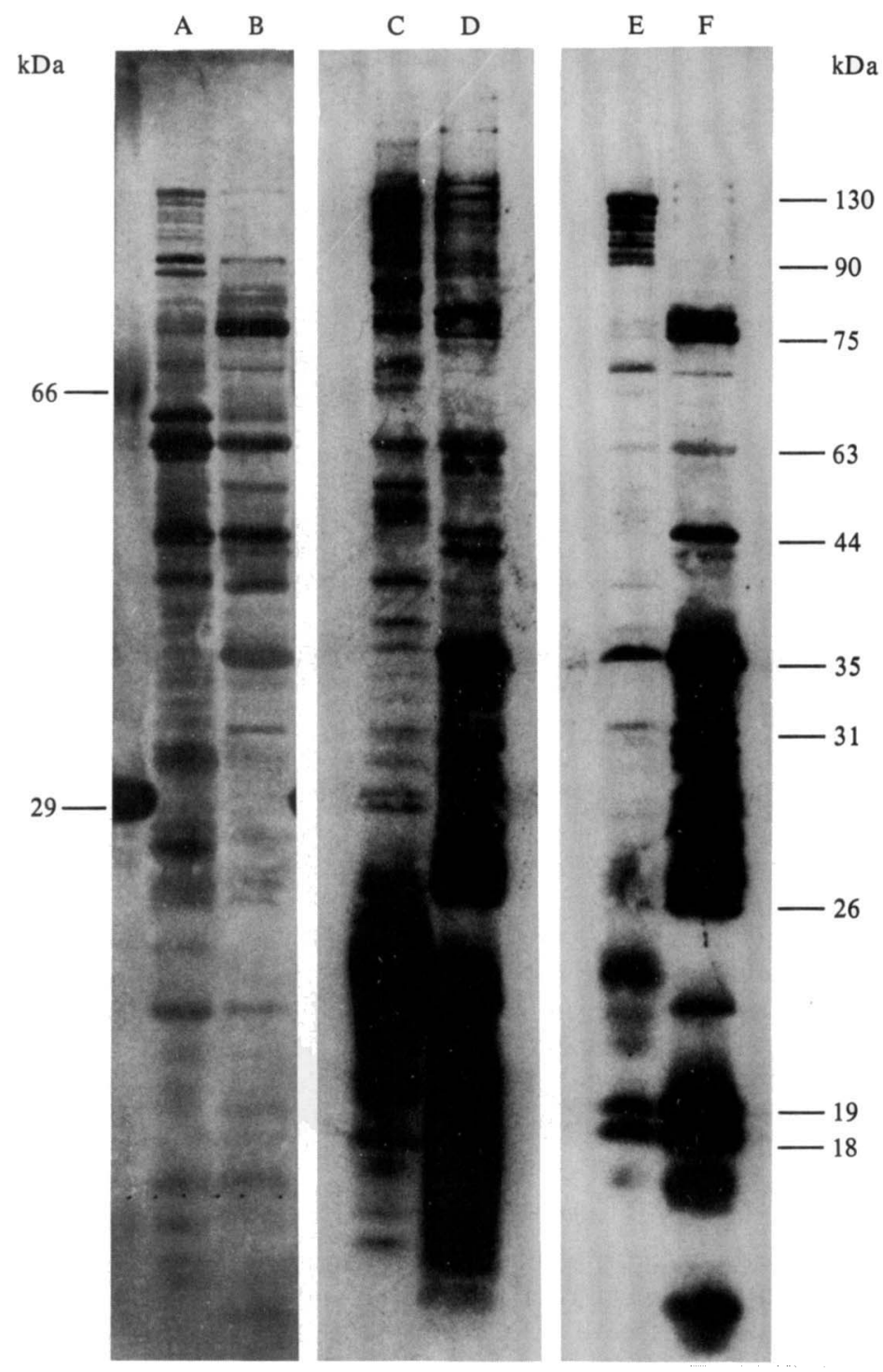

Fig. 4. Western blots of proteins separated by SDS-PAGE and extracted from whole cells with SLS (lanes A, C and E) or from the cell-envelope fraction with SDS/2-MeH (lanes B, D and F). Lanes A and $B$ are India ink stains of the transferred proteins; lanes $C$ and $D$ are autoradiograms of blots reacted with whole-cell antiserum and then [125I]Protein $A$; lanes $E$ and $F$ are autoradiograms of blots reacted with antiserum to culture supernatant proteins and then [125I]Protein A. The molecular mass marker proteins of $66 \mathrm{kDa}$ and $29 \mathrm{kDa}$ were electroblotted and stained with ink (left). Other protein bands are labelled according to their approximate molecular masses. Each gel lane contained $30 \mu \mathrm{g}$ protein (Lowry).

\section{Characterization of antigens by immunoblotting}

To characterize further the proteins present in the SLS and envelope extracts, and to attempt to relate some of these to the wall antigens of $S$. sanguis described by others (Schöller et al., 1982; Rosan \& Appelbaum, 1982; Liljemark \& Bloomquist, 1981), proteins were reacted with either whole-cell antibodies or antibodies made to culture supernatant proteins. The proteins that had been separated by SDS-PAGE were electrolytically transferred to nitrocellulose and reacted with the antisera. The antigen-antibody complexes were detected by incubating the blots with 


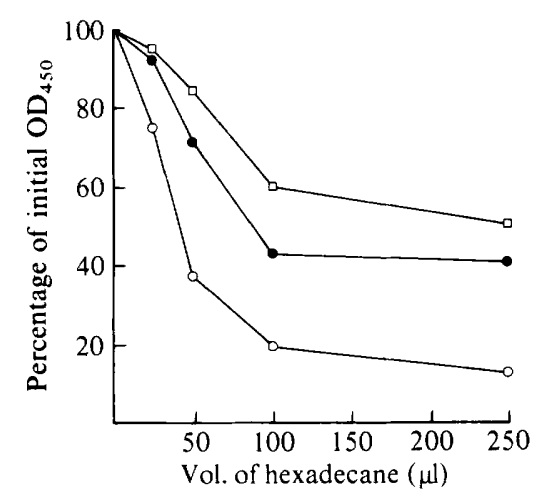

Fig. 5. Adsorption of $S$. sanguis cells to hexadecane. Cells were vortex-mixed with hexadecane, allowed to settle and the $\mathrm{OD}_{450}$ of the aqueous phase was measured. $\bigcirc$, Control; $\bigcirc$, SLS-treated cells; $\square$, pronase-treated cells. Details of the treatments are described in Methods. The experiment was repeated four times and data are individual values from a representative experiment.

[125I]Protein $\mathrm{A}$ and then autoradiographing them. The transfer of the proteins to nitrocellulose was monitored by staining the blots with India ink (Fig. 4, lanes A and B). Proteins of molecular mass $<20 \mathrm{kDa}$ were not efficiently transferred. A comparison of the blots reacted with wholecell antibodies suggests a number of antigens (e.g. $130 \mathrm{kDa}, 90 \mathrm{kDa}$ and $63 \mathrm{kDa}$ proteins) are common to both the SLS and envelope extracts (Fig. 4, lanes C and D). The major reactive antigens in the envelope extract (about 10 between 26 and $35 \mathrm{kDa}$; Fig. 4, lane D) were not present in the SLS extract. The 20-24 kDa group of proteins in the SLS extract reacted with the whole-cell antibodies (Fig. 4, lane C).

Fewer of the polypeptides in the SLS extract reacted with antibodies to supernatant proteins (Fig. 4, lane E). A group of proteins (130-90 kDa) and the 63 and $35 \mathrm{kDa}$ proteins reacted, suggesting these antigens are secreted into the culture fluid; the $20-24 \mathrm{kDa}$ group of proteins did not react. Most of the major envelope polypeptides reacted with antibodies raised to culture supernatant proteins (Fig. 4, lane F), showing that these are secreted during growth of the cells. There was no reaction of any of the antigens on the blots with rabbit pre-immune serum $(1 / 100$ dilution).

\section{Effect of protease and SLS treatments on cell hydrophobicity}

To determine if the components of the SLS extract conferred hydrophobicity to the cell surface (and might therefore be involved in cell adhesion), cells treated with SLS or protease were tested for their ability to adsorb to the hydrophobic hydrocarbon hexadecane. Cells that were treated with SLS or pronase $\left(100 \mu \mathrm{g} \mathrm{ml}^{-1}, 20 \mathrm{~min}, 20^{\circ} \mathrm{C}\right.$ ) had reduced hydrophobicity (Fig. 5 ), as shown by lowering of affinity of the cells for hexadecane. Initially, adsorption to xylene (Rosenberg et al., 1983) was also used as a measure of cell hydrophobicity, but this did not give consistent results between experiments as it caused lysis.

Since both protease and SLS treatments reduced cell hydrophobicity, components of the SLS extract were probably hydrophobic. To test this, a portion of SLS extract containing about $20 \mu \mathrm{g}$ protein was subjected to hydrophobic interaction chromatography on Octyl-Sepharose. After applying the extract to the column (Fig. 6, lane A) and washing out unbound materials (see Methods), adsorbed proteins were eluted with a gradient of decreasing ammonium sulphate concentration and simultaneously increasing SLS concentration. The polypeptides in the 20-24 $\mathrm{kDa}$ range were not retained in the column, but the $16 \mathrm{kDa}$ protein was (Fig. 6), showing that it was the major hydrophobic protein component of the SLS extract.

Effect of $S L S$ or protease treatments on coaggregation of $S$. sanguis with $A$. viscosus $T 14 \mathrm{~V}$ and A. naeslundii W1544

Glucose-grown cells of $S$. sanguis strain OB11 aggregated with cells of both $A$. viscosus and A. naeslundii, forming clumps that settled over several hours (Table 2). Pronase-treated cells of 

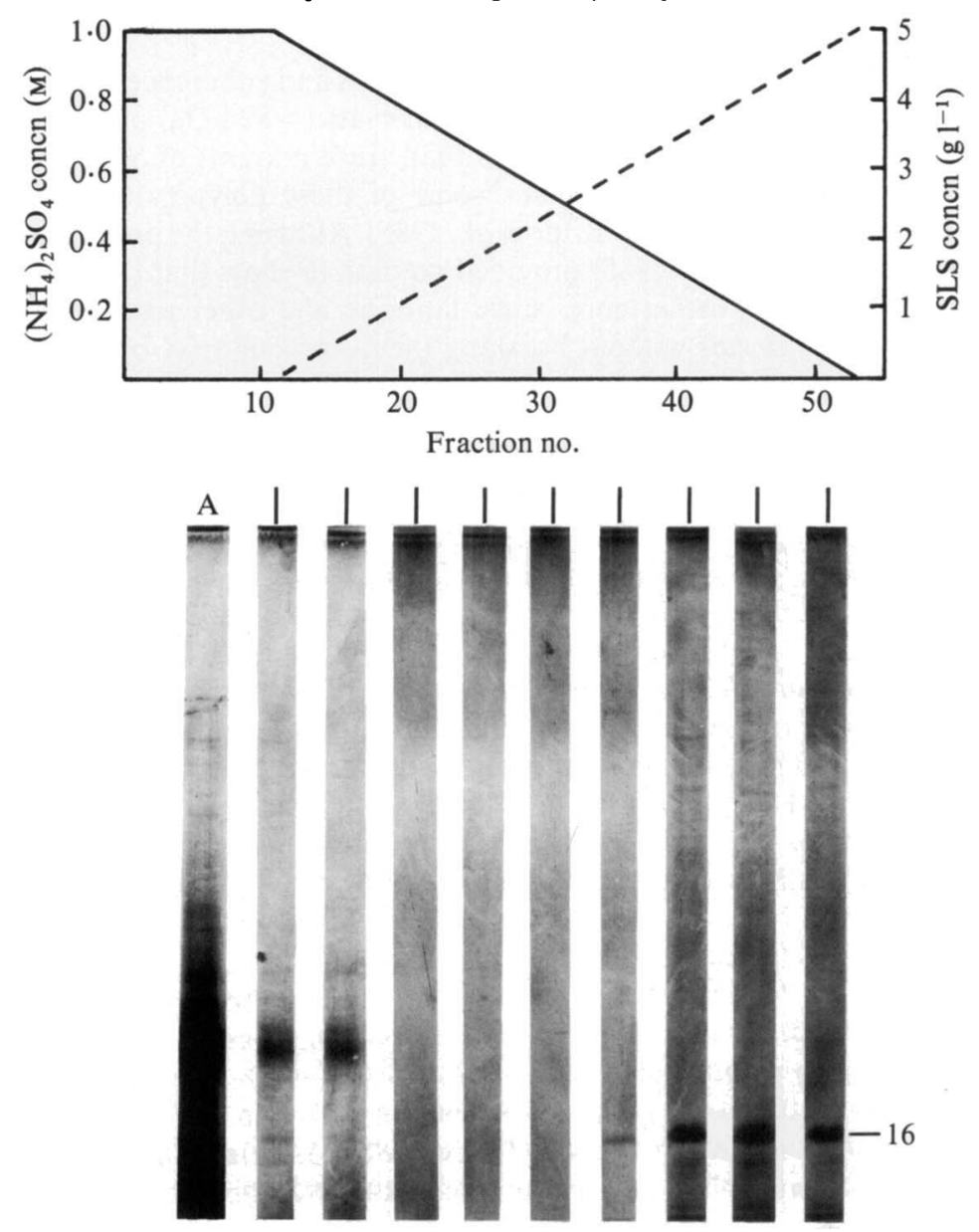

Fig. 6. Separation of proteins in SLS extract by hydrophobic interaction chromatography. Approximately $20 \mu \mathrm{g}$ protein in $1 \mathrm{M}-\left(\mathrm{NH}_{4}\right)_{2} \mathrm{SO}_{4}$ was applied to a column of Octyl-Sepharose CL-4B. Lane $\mathrm{A}$ is an SDS-PAGE profile (stained with silver nitrate) of a portion of the extract applied to the column. The column was eluted with a gradient of decreasing $\left(\mathrm{NH}_{4}\right)_{2} \mathrm{SO}_{4}$ concentration and simultaneously increasing SLS concentration (final concentrations 0 and $5 \mathrm{~g} \mathrm{l}^{-1}$ respectively). The SDSPAGE profile of proteins (stained with silver nitrate) in every fifth fraction is shown, and the position of the $16 \mathrm{kDa}$ protein is indicated.

\section{Table 2. Effect of pronase or SLS treatments on coaggregation properties of $S$. sanguis}

Percentage coaggregation was estimated spectrophotometrically (see Methods). Numbers in parentheses are visual coaggregation scores on a scale from zero (none) to four (maximum). Experiments were repeated twice; results are mean values for replicates within one experiment.

\begin{tabular}{lcc} 
& \multicolumn{2}{c}{ Percentage coaggregation with: } \\
Treatment & A. riscosus T14V & A. naeslundii W1544 \\
None & $49(4)$ & $43(4)$ \\
Pronase & $38(2)$ & $41(4)$ \\
SLS & $22(1)$ & $28(1)$
\end{tabular}

$S$. sanguis did not aggregate as well with $A$. viscosus as did untreated cells (Table 2), but their aggregation with $A$. naeslundii was not significantly affected (Table 2). Treatment of $S$. sanguis cells with SLS considerably reduced their ability to coaggregate with both $A$. viscosus and $A$. naeslundii (Table 2). Thus, the SLS-extracted material contained components necessary for coaggregation, as well as for cell hydrophobicity. 


\section{Discussion}

In studying the relationship between cell-surface proteins and adherence of $S$. sanguis, interest has been recently centred on a class of high molecular mass $(>80 \mathrm{kDa})$ proteins present in the cell wall (McBride et al., 1985). It was suggested that, since mutants of $S$. sanguis that are less hydrophobic than the parent strain also lack some of these polypeptides, the proteins are associated with cell hydrophobicity (McBride et al., 1985). Although the proteins were present in isolated cell walls, McBride et al. (1985) provided no data to show that the polypeptides were exposed at the cell surface. Furthermore, since fimbriae and other surface antigens can be removed from cells of $S$. sanguis without breaking them (for example, by pulse-blending; see Fachon-Kalweit et al., 1985), surface components conferring hydrophobic or adherence properties may be absent from cell wall preparations. The work described in this paper identifies proteins present at the cell surface, probably within the fibrillar coat, by gently extracting whole cells and then subjecting the extracts to SDS-PAGE on gels that separate proteins over a wide range of molecular mass (about $150 \mathrm{kDa}$ to $12 \mathrm{kDa}$ ).

Extraction of cells with SLS at room temperature removed proteins from the cell surface and also material similar in composition to that extracted from cells with hot aqueous phenol; this includes lipoteichoic acid (Wicken \& Knox, 1975; Rosan, 1978), polynucleotides and polysaccharides (Chiu et al., 1974; Emdur et al., 1974). The protein composition of the extract was not phenotypically variable, and was similar for serotype 1 and serotype 2 strains of $S$. sanguis that were tested. The major protein components (seven proteins in a group between 20 and $24 \mathrm{kDa}$, and a $16 \mathrm{kDa}$ protein) have not previously been identified, and they are not prominent components of either the extracellular culture fluid or the cell-envelope fraction prepared from mechanically broken cells. All the constituents of the SLS extract were shown to be accessible at the cell surface except for five of the 20-24 kDa group of proteins, which were not surface-iodinated or degraded by pronase-treating cells. These experiments do not rule out the possibility that the $20-24 \mathrm{kDa}$ proteins may be surface components, and the observation that they reacted with antibodies raised to fixed cells indeed suggests that they are.

The $16 \mathrm{kDa}$ protein is hydrophobic, exposed at the cell surface and constitutes at least $0.3 \%$ of total cell protein. The protein is degraded when cells are treated with pronase, and is extracted with SLS, both treatments that reduce cell hydrophobicity. This suggests that the $16 \mathrm{kDa}$ polypeptide may confer hydrophobic properties to the cell surface. A similar property has been attributed to the $M$ protein present on the surface of group A streptococcal cells. Protease treatment of $S$. pyogenes degrades the $M$ protein leaving the fibrillar coat intact (Beachey \& Ofek, 1976), while $\mathbf{M}^{-}$strains are less hydrophobic than $\mathbf{M}^{+}$strains (Wadström et al., 1984).

It is apparent from surface-labelling cells with ${ }^{125}$ I that at least 30 polypeptides extractable with SLS are exposed at the cell surface. A somewhat similar SDS-PAGE profile to that in Fig. 2 was obtained by Appelbaum \& Rosan (1984) when iodinated cells of $S$. sanguis were extracted with boiling SDS. Surface proteins on $S$. sanguis have been implicated by various authors in conferring hydrophobicity and adherence properties. For example, Rosan \& Appelbaum (1982) described the loss of 86,92 and $160 \mathrm{kDa}$ proteins from the surface of $S$. sanguis on protease treatment, Liljemark \& Bloomquist (1981) partly purified an $86 \mathrm{kDa}$ adhesin from the cell surface, and Schöller et al. (1982) isolated a soluble wall-associated common protein antigen of about $60 \mathrm{kDa}$ from various oral bacteria including $S$. sanguis. Proteins in the wall of higher molecular mass (>130 kDa) have also been described (McBride et al., 1985; Knox et al., 1985); some of these had glucosyl transferase activity (Knox et al., 1985) and others cross-reacted with antiserum to $S$. mutans wall antigens B and I/II (Forester et al., 1983).

Hydrophobic interactions are involved in adhesion of $S$. sanguis (Nesbitt et al., 1982a; Gibbons \& Etherden, 1983) but Knox et al. (1985) have recently shown that there is no direct correlation between cell hydrophobicity and the ability of $S$. sanguis to adhere to saliva-coated hydroxyapatite. Thus, a measurement of hydrophobicity is not necessarily an index of the ability of cells to adhere; hydrophobicity should be considered a phenotypic property of the cells, which can be changed by altering the composition of the cell surface. The $16 \mathrm{kDa}$ polypeptide is on the cell surface of $S$. sanguis and is hydrophobic, but it may not necessarily be involved in cell adherence. In more general terms, though, treating the cells with SLS reduced their 
hydrophobicity and appeared to remove fibrillar surface structures. This observation is in keeping with the suggestions of Gibbons et al. (1983) and Fives-Taylor \& Thompson (1985) that components of the fibrillar coat confer hydrophobicity to the cell. In addition, treating the cells with SLS reduced their ability to coaggregate with both $A$. viscosus and $A$. naeslundii. The extraction method is thus effective in removing, from the cell surface, molecules determining both hydrophobic and coaggregation properties. Components of the SLS extract are currently being purified in order to determine precisely which ones are involved in cell adherence.

I thank Miss N. J. Lees for technical assistance, Mr P. G. Ashworth for electron microscopy, and Professor M. G. Shepherd for helpful discussions. This work was supported, in part, by the Medical Research Council of New Zealand, and a grant from the New Zealand Dental Research Foundation Board is gratefully acknowledged.

\section{REFERENCES}

Appelbaum, B. \& Rosan, B. (1984). Cell surface proteins of oral streptococci. Infection and Immunity 46, 245-250.

ARCHibald, A. R. (1972). Teichoic acids. Methods in Carbohydrate Chemistry 6, 162-172.

BeACHEY, E. H. \& OFEK, I. (1976). Epithelial cell binding of group A streptococci by lipoteichoic acid on fimbriae denuded of $\mathbf{M}$ protein. Journal of Experimental Medicine 143, 759-771.

Carlsson, J. (1972). Nutritional requirements of Streptococcus sanguis. Archives of Oral Biology 17, 1327-1332.

Chen, P. S., Jr, Toribara, T. Y. \& Warner, H. (1956). Microdetermination of phosphorus. Analytical Chemistry 28, 1756-1758.

Chiu, T. H., Emdur, L. I. \& Platt, D. (1974). Lipoteichoic acids from Streptococcus sanguis. Journal of Bacteriology 118, 471-479.

Cisar, J. O., Kolenbrander, P. E. \& Mcintire, F. C. (1979). Specificity of coaggregation reactions between human oral streptococci and strains of Actinomyces viscosus or Actinomyces naeslundii. Infection and Immunity 24, 742-752.

Cole, R. M., Calandra, G. B., Huff, E. \& Nugent, K. M. (1976). Attributes of potential utility in differentiating among 'group $\mathrm{H}^{\prime}$ streptococci or Streptococcus sanguis. Journal of Dental Research 55 , A142-A153.

Dubois, M., Gilles, K. A., Hamilton, J. K., Rebers, P. A. \& SMITH, F. (1956). Colorimetric method for determination of sugars and related substances. Analytical Chemistry 28, 350-354.

EIFERT, R., Rosan, B. \& Golub, E. (1984). Optimization of an hydroxyapatite adhesion assay for Streptococcus sanguis. Infection and Immunity $\mathbf{4 4}$, 287-291.

Ellen, R. P. \& Gibbons, R. J. (1972). M proteinassociated adherence of Streptococcus pyogenes to epithelial surfaces: prerequisite for virulence. Infection and Immunity 5, 826-830.

Emdur, L. I., Saralkar, C., McHugh, J. G. \& Chiu, T. H. (1974). Glycerolphosphate-containing cell wall polysaccharides from Streptococcus sanguis. Journal of Bacteriology 120, 724-734.

Fachon-Kalweit, S., Elder, B. L. \& Fives-Taylor, P. (1985). Antibodies that bind to fimbriae block adhesion of Streptococcus sanguis to saliva-coated hydroxyapatite. Infection and Immunity 48, 617624.
Fairbanks, G., Steck, T. L. \& Wallach, D. F. H. (1971). Electrophoretic analysis of the major polypeptides of the human erythrocyte membrane. Biochemistry 10, 2606-2617.

FIVES-TAYLOR, P. M. \& ThOMpson, D. W. (1985). Surface properties of Streptococcus sanguis FW213 mutants nonadherent to saliva-coated hydroxyapatite. Infection and Immunity 47, 752-759.

Forester, H., HUNTER, N. \& KNOX, K. W. (1983). Characteristics of a high molecular weight extracellular protein of Streptococcus mutans. Journal of General Microbiology 129, 2779-2788.

GibBons, R. J. \& Etherden, I. (1983). Comparative hydrophobicities of oral bacteria and their adherence to salivary pellicles. Infection and Immunity 41, 1190-1196.

GibBons, R. J. \& NyGaARD, M. (1970). Interbacterial aggregation of plaque bacteria. Archives of Oral Biology 15, 1397-1400.

GibBons, R. J. \& VAN Houte, J. (1975). Bacterial adherence in oral microbial ecology. Annual Review of Microbiology 29, 19-44.

Gibbons, R. J., Etherden, I. \& Skobe, Z. (1983). Association of fimbriae with the hydrophobicity of Streptococcus sanguis FC-1 and adherence to salivary pellicles. Infection and Immunity 41, 414-417.

Greenwood, F. C., Hunter, W. M. \& Glover, J. S. (1963). The preparation of ${ }^{131}$ I-labelled human growth hormone of high specific radioactivity. Biochemical Journal 89, 114-123.

Hamada, S. \& Slade, H. D. (1980). Biology, immunology and cariogenicity of Streptococcus mutans. Microbiological Reviews 44, 331-384.

HANCOCK, K.\& TsANG, V. (1983). India ink staining of proteins on nitrocellulose paper. Analytical Biochemistry 133, 157-162.

Handley, P. S., Carter, P. L., Wyatt, J. E. \& Hesketh, L. M. (1985). Surface structures (peritrichous fibrils and tufts of fibrils) found on Streptococcus sanguis strains may be related to their ability to coaggregate with other oral genera. Infection and Immunity 47, 217-227.

HANSEN, S. A. (1975). Thin-layer chromatographic method for the identification of mono-, di- and trisaccharides. Journal of Chromatography 107, 224227.

Hardie, J. M. \& Bowden, G. H. (1976). Physiological classification of oral viridans streptococci. Journal of Dental Research 55, Al66-A176. 
van Houte, J., Gibbons, R. J. \& Banghart, S. B. (1970). Adherence as a determinant of the presence of Streptococcus salivarius and Streptococcus sanguis on the human tooth surface. Archives of Oral Biology 15, 1025-1034.

Jenkinson, H. F., Sawyer, W. D. \& Mandelstam, J. (1981). Synthesis and order of assembly of spore coat proteins in Bacillus subtilis. Journal of General Microbiology 123, 1-16.

Kessler, R. E. \& Shockman, G. D. (1979). Precursorproduct relationship of intracellular and extracellular lipoteichoic acids of Streptococcus faecium. Journal of Bacteriology 137, 869-877.

KNOX, K. W., Hardy, L. N., Markevics, L. J., Evans, J. D. \& WiCKen, A. J. (1985). Comparative studies on the effect of growth conditions on adhesion, hydrophobicity and extracellular protein profile of Streptococcus sanguis G9B. Infection and Immunity 50, 545-554.

Kolenbrander, P. E. \& Williams, B. L. (1981). Lactose-reversible coaggregation between oral actinomycetes and Streptococcus sanguis. Infection and Immunity 33, 95-102.

LAEMMLI, U. K. \& FAVRE, M. (1973). Maturation of the head of bacteriophage T4. I. DNA packaging events. Journal of Molecular Biology 80, 575-599.

Liljemark, W. F. \& Bloomquist, C. G. (1981). Isolation of a protein-containing cell surface component from Streptococcus sanguis which affects its adherence to saliva-coated hydroxyapatite. Infection and Immunity 34, 428-434.

McBride, B. C., Morris, E. J. \& Ganeshiumar, N. (1985). Relationship of streptococcal cell surface proteins to hydrophobicity and adherence. In $\mathrm{Mol}$ ecular Basis of Oral Adhesion, pp. 85-93. Edited by S. E. Mergenhagen \& B. Rosan. Washington, DC: American Society for Microbiology.

ManN, A. F., Hucklesby, D. P. \& Hewitt, E. J. (1979). A modified Hanes and Isherwood spray for improved detection of phosphate esters in thin layer chromatography. Analytical Biochemistry 96, 6.

Marchalonis, J. J. (1969). An enzymic method for the trace iodination of immunoglobulins and other proteins. Biochemical Journal 113, 299-305.

Merril, C. R., Goldman, D., Sedmen, S. A. \& Ebert, M. H. (1981). Ultrasensitive stain for proteins in polyacrylamide gels shows regional variation in cerebrospinal fluid proteins. Science 211, 1437-1438.

Murray, P. A., Levine, M. J., Tabak, L. A. \& Reddy, M. S. (1982). Specificity of salivary-bacterial interactions. II. Evidence for a lectin on Streptococcus sanguis with specificity for a NeuAc $\alpha 2,3 \mathrm{Gal} \beta 1$, $3 \mathrm{GlcNac}$ sequence. Biochemical and Biophysical Research Communications 106, 390-396.

Nesbitt, W. E., StaAt, R. H., Rosan, B., Taylor, K. G. \& DOYLE, R. J. (1980). Association of protein with the cell wall of Streptococcus mutans. Infection and Immunity 28, 118-126.

Nesbitt, W. E., Doyle, R. J. \& TAylor, K. G. (1982a). Hydrophobic interactions and the adherence of Streptococcus sanguis to hydroxylapatite. Infection and Immunity 38, 637-644.

Nesbitt, W. E., Doyle, R. J., Taylor, K. G., StaAt, R. H. \& ARNold, R. R. (1982b). Positive cooperativity in the binding of Streptococcus sanguis to hydroxylapatite. Infection and Immunity 35, 157-165.
Nugent, K. M. \& Cole, R. M. (1977). Characterization of group $\mathrm{H}$ streptococcal temperate bacteriophage $\phi 227$. Journal of Virology 21, 1061-1073.

Ogier, J. A., Klein, J. P., Sommer, P. \& Frank, R. M. (1984). Identification and preliminary characterization of saliva-interacting surface antigens of Streptococcus mutans by immunoblotting, ligand blotting and immunoprecipitation. Infection and Immunity 45, $107-112$.

Rosan, B. (1973). Antigens of Streptococcus sanguis. Infection and Immunity 7, 205-211.

Rosan, B. (1978). Absence of glycerol teichoic acid in certain oral streptococci. Science 201, 918-920.

RoSAN, B. \& A PPELBAUM, B. (1982). Surface receptors of selected oral streptococci and their role in adhesion to hydroxyapatite. In Microbiology - 1982, pp. 342-345. Edited by D. Schlessinger. Washington, DC: American Society for Microbiology.

RosenberG, W., GuTNICK, D. \& RosenberG, E. (1980). Adherence of bacteria to hydrocarbons: a simple method for measuring cell-surface hydrophobicity. FEMS Microbiology Letters 9, 29-33.

Rosenberg, M., Judes, H. \& Weiss, E. (1983). Cell surface hydrophobicity of dental plaque microorganisms in situ. Infection and Immunity 42, 831-834.

Russell, R. R. B. (1979). Wall-associated protein antigens of Streptococcus mutans. Journal of General Microbiology 114, 109-115.

Sato, S., Koga, T. \& Inoue, M. (1984). A possible mechanism for the cellular coaggregation between Actinomyces viscosus ATCC 19246 and Streptococcus sanguis ATCC 10557. Journal of General Microbiology 130, 1351-1357.

SChöller, M., Klein, J. P., Sommer, P. \& Frank, R. (1982). Common antigens of streptococcal and nonstreptococcal oral bacteria: isolation and biochemical characterization of the extracellular protein antigen. Journal of General Microbiology 128, 21132120 .

Smith, R., Lehner, T. \& Beverley, P. C. L. (1984). Characterization of monoclonal antibodies to Streptococcus mutans antigenic determinants I/II, I, II and III and their serotype specificities. Infection and Immunity 46, 168-175.

Swanson, J., King, G. \& Zeligs, B. (1975). Studies on gonococcus infection. VIII. ${ }^{125}$ Iodine labelling of gonococci and studies on their in vitro interactions with eukaryotic cells. Infection and Immunity 11, 453459.

Towbin, H., Staehelin, T. \& Gordon, J. (1979). Electrophoretic transfer of proteins from polyacrylamide gels to nitrocellulose sheets: procedure and some applications. Proceedings of the National Academy of Sciences of the United States of America 76, 4350-4354.

Wadström, T., Schmidt, K.-H., Kühnemund, O., HAVliceK, J. \& KöHLER, W. (1984). Comparative studies on surface hydrophobicity of streptococcal strains of groups A, B, C, D and G. Journal of General Microbiology 130, 657-664.

WEERKAMP, A. H. \& JACOBS, T. (1982), Cell wallassociated protein antigens of Streptococcus salivarius: purification, properties and function in adherence. Infection and Immunity 38, 233-242.

WeERKAMP, A. H. \& McBRIDE, B. C. (1981). Identification of a Streptococcus salivarius cell wall compo- 
nent mediating coaggregation with Veillonella alcalescens V1. Infection and Immunity 32, 723-730.

WiCKEN, A. J. \& KNoX, K. W. (1975). Lipoteichoic acids: a new class of bacterial antigen. Science 187, 1161-1167.
Wicken, A., Gibbens, J. W. \& Knox, K. W. (1973). Comparative studies on the isolation of membrane lipoteichoic acid from Lactobacillus fermenti. Journal of Bacteriology 113, 365-372. 